University at Buffalo School of Law

Digital Commons @ University at Buffalo School of Law

\title{
A Critique of Rights in Transitional Justice: The African Experience
}

Makau wa Mutua

University at Buffalo School of Law, mutua@buffalo.edu

Follow this and additional works at: https://digitalcommons.law.buffalo.edu/book_sections

Part of the Human Rights Law Commons

\section{Recommended Citation}

Makau W. Mutua, A Critique of Rights in Transitional Justice: The African Experience in Rethinking Transitions: Equality and Social Justice in Societies Emerging from Conflict 31 (Gaby Oré Aguilar \& Felipe Gómez Isa, eds., Intersentia 2011)

Originally published in the book Rethinking Transitions: Equality and Social Justice in Societies Emerging from Conflict, edited by Gaby Ore Aguilar \& Felipe Gomez Isa, ISBN 978-1-78068-003-3, Intersentia, Cambridge - Antwerp - Portland, 2011.

\section{IN COPYRIGHT}

This Book is brought to you for free and open access by the Faculty Scholarship at Digital Commons @ University at Buffalo School of Law. It has been accepted for inclusion in Contributions to Books by an authorized administrator of Digital Commons @ University at Buffalo School of Law. For more information, please contact lawscholar@buffalo.edu. 


\title{
A CRITIQUE OF RIGHTS IN TRANSITIONAL JUSTICE: THE AFRICAN EXPERIENCE
}

\author{
Makau MutuA
}

\section{INTRODUCTION}

In the last two decades, the concept of transitional justice has come to represent the midwife for a democratic, rule ofdaw state. ${ }^{1}$ The script for the construction of such a phase is now regarded as an indispensable building block for sound constitutionalism, peace-building, and national reconciliation in post-conflict societies or societies emerging out of abusive, authoritarian, and fractured periods. ${ }^{2}$ In fact, policy-makers and statesmen now increasingly realize that a human rights state that internalizes human rights norms cannot be created unless the political society concretely addresses the grievances of the past. There is no future without a past, and the future is largely a result of the past. Unless we construct a future based on the lessons of the past, we are bound to repeat our own mistakes and retard the development of our society.

The term transitional justice captures two critical notions. First, it acknowledges the temporary measures that must be taken to build confidence in the construction of the post-despotic society. Secondly, by its own definition, transitional justice rejects a winner-take-all approach as a beachhead to the future. In other words, transitional justice calls for deep concessions on either side of the divide. No one party or faction can be fully satisfied. Unyielding, none concessionary demands can only foil the truce that is essential for national reconstruction. But equally important is the realisation that transitional justice rejects impunity for the most hideous offenders. To shield egregious perpetrators would only encourage a culture of unaccountability for past abuses. Hence a

\footnotetext{
1 Priscilla Hayner, Unspeakable Truths, Confronting State Terror and Atrocities, Routledge New York, $1^{\text {st }}$ ed. December 2000. A revised edition of this book has been recently published in 2010.

2 Desmond Tutu, No Future Without Forgiveness, First Image Book editions, New York, 1999.
} 
balance must be struck between justice for the victims and retribution against offenders. ${ }^{3}$

But the vast majority of states lack the requisite political will to effect transformative transitions. That is why most political transitions are either still born or aborted affairs. For Africa, this calls for soul-searching at all levels of society - within the political class, among the intelligentsia, in civil society, and the general public. In other words, Africans must ask themselves: Is transitional justice a necessity for us if we are to create a democratic polity? If so, what vehicles should we construct to effect transitional justice, and what mandate shall we give such vehicles? But even as we ask these questions, we must remain mindful about the cost of abandoning transitional justice measures. The reason for this is simple: We cannot exorcise the ghosts of the past without confronting them. The past will always be with us.

Even if we accept as a basic premise - which we do - that transitional justice processes and institutions are desirable and indispensable, we would be derelict not to interrogate the internal contradictions of the human rights project. I say so because the human rights project, which encompasses transitional justice, is an incomplete doctrine that is afflicted by gaping holes. ${ }^{4}$ International human rights law, perhaps the most important transformational idea of our times, is fraught with conceptual and cultural problems. Human rights norms seek to impose an orthodoxy that would wipe out cultural milieus that are not consonant with liberalism and Eurocentrism. While it is useful to develop international standards for human rights, it is imperative that we understand the complexity of the diversity of our world, and work to create doctrinally inclusive and normatively multicultural formulae for dealing with human rights and social justice. Otherwise, we will lose the liberatory potential of human rights and fail to reconstruct societies that need recreation. While no society can truly emerge from a legacy of conflict and violence without the implementation of serious social justice measures, such an exercise cannot be carried out in a cultural vacuum. For Africa, it is essential to recognize that communities and collectives are an integral part of social reality. As such, the individualist focus of the human rights corpus must be tempered with communalist or group-oriented approaches if human rights prescriptions are going to enjoy any legitimacy on the continent. $^{5}$

3 Martha Minow, Between Vengeance and Forgiveness: Facing History After Genocide And Mass Violence, Beacon Press, Boston, 1998.

4 MaKau Mutua, Human Rights: A Political and Cultural Critique, University of Pennsylvania Press, Pennsylvania, 2002.

5 Makau Mutua, "The Transformation of Africa. A Critique of the Rights Discourse", in Felipe Gramz Isa and Koen De Feyter (eds.), International Human Rights Law in a Global Context, Deusto University Press, Bilbao, 2009, pp. 899-924. 
The last fifty years represent the entire period of the African post-colonial state, and gives us a fantastic window through to interrogate the performance of the human rights project in Africa. But first, I want to lay aside some misconceptions about the human rights corpus and the movement. At the outset, though, I want to level with you about the subject of intellectual bias or normative location. Even though objectivity is the name of our game, we are nevertheless products of our legacies and heritages that have forged our identity and philosophical outlooks. In that sense, true objectivity is an academic fiction, for no one could be truly objective. In any case, if we were truly objective, we would be truly boring. And so, I want to plead my biases at the outset. But I also want to warn you that with respect to the subject at hand - that of the utility of human rights and liberalism in Africa - I adopt the view of an insider-outsider, an engaged skeptic who completely believes in human dignity, but is not sure about the typology of political society that ought to be constructed to get us there.

I want to suggest that human rights are imprisoned in universality, one of the central proclivities of liberalism. This fact alone should give us pause about human rights because we ought to approach all claims of universality with caution and trepidation. I say this because visions of universality and predestination have often been intertwined throughout modern history. And that intersection of universality and predestination has not always been a happy one: with an alarming frequency, liberalism's key tenets have been deployed to advance narrow, sectarian, hateful, and exclusionary practices and ideas. So, at the purely theoretical level, we are chastised to look not once - but twice, and again - at universalizing creeds, ideas, and phenomena. This is not to suggest that universality is always wrongheaded, or even devious, although it has frequently been those things as well - but it is rather to assume that the universality of social phenomena is not a natural occurrence. Universality is always constructed by an interest for a specific purpose, with a specific intent, and a projected substantive outcome in mind.

This critical view has special implications for Africa because it questions both the fit and utility of liberalism and human rights for the continent. If we agree that all social truths are initially local - even truths about the so-called natural attributes of human beings or the purposes of political society - what does that say about the assumptions of liberalism in Africa? If social truths are contextual, cultural, historical, and time-bound, how can one find the relevance of the human rights project in Africa? This is not to say that local truths cannot be transformed into universal truths. They can, but the question for students of Africa is how one gets from here to there - in other words, what are the limitations of liberalism in general, and human rights in particular, as transnational projects? How do we turn local claims into universal human rights 
claims? If it is desirable to put liberalism in the service of Africa, how does one do so?

\section{HUMAN RIGHTS AND THE AFRICAN REALITY}

Assuming these basic philosophical difficulties, how can human rights as conceived be of any help to the reconstruction and recovery of the African postcolonial state? Five decades after decolonization, the African state is still haunted by crises of geographic, political, and moral legitimacy. It is beset by the protracted reality of national incoherence and the ills of economic underdevelopment. At its dawn, the African post-colonial state was handed a virtually impossible task - assimilate the norms of the liberal tradition overnight within the structures of the colonial state while at the same time building a nation from disparate groups in a hostile international political economy. Instead, the newly minted African post-colonial elites chose first to consolidate their own political power. We can blame them now, as I have, but we must also understand that the first instinct of the political class is to consolidate itself and concentrate power in its own hands.

In the Cold War context, this frequently meant stifling dissent, dismantling liberal constitutions, retreating to tribal loyalties or sycophantic cronies, and husbanding state resources for corruption or patronage purposes. In other words, any viable fabric of the post-colonial state started to crumble even before it was established. We know the rest - coups and countercoups, military regimes, and one-party dictatorships with the inevitable results of economic decay; collapse of infrastructure; the fragmentation of political society; bilious re-tribalization; religious, sectarian, and communal conflicts and civil wars; and state collapse in a number of cases. The achievement of political independence from colonial rule turned into false renaissance as one African after another experienced transitional difficulties. While the African state retained some form of international legitimacy, its domestic writ was wafer thin. It was a miracle that many African states did not implode altogether given the challenges of internal legitimacy. Whatever the case, the liberal tradition failed to take hold as human rights were violated across the board.

However, the 1980s saw a resurgence of civil society and the re-emergence of the political opposition. This started what has come to be loosely referred to as the Second Liberation. The entire continent was rocked by a wave of political liberalization not witnessed since the 1950s and 1960s. Virtually all states succumbed to some political reform. In all cases, the civil society and the political opposition sought a new social compact framed by the tenets of the 
liberal tradition. These were the rule of law, political democracy through multipartyism, checks on executive power, limitations on the arbitrary use of state power, judicial independence, directly elected and unencumbered legislatures, separation of powers, freedoms of the press, speech, assembly, and association - in a word, the whole gamut of civil and political rights or the full complement of so-called basic human rights.

It was as though Africans were asking to go back to the liberal constitutions imposed by the departing colonial powers. In some cases, new constitutional orders were established to respond to these demands. But a decade a half after the frenzy to reintroduce the liberal tradition to the politics of Africa, we cannot count many blessings because the tumult of political liberalization has yielded very mixed results. Optimists see a steady progression, even though the reversals have been many and discouraging. Pessimists or what one might even want to call realists, see an African state that is a stubborn predator, unable and unwilling to accept reform. For every one step forward, there seems to be several steps back. The near meltdown of Kenya in the aftermath of the December 2007 is only one case in point. ${ }^{6}$

Is the African state impervious to human rights and the liberal tradition, or is the problem much more serious? The fault is variously placed on a bankrupt elite or political class; structural impediments within the state - ethnicity, religious zealotry, underdevelopment, the failure to establish a legitimate political order, social cleavages; an unyielding international economic order. Whatever the case, the jury on the current process of political liberalization, which is taking place at the same time with economic globalization, is still out. It is still too early to say for certain whether the African post-colonial state is out of the woods yet.

\section{CAN HUMAN RIGHTS RECOVER THE AFRICAN STATE?}

The limitations that curtail the ability of the human rights corpus to respond to Africa's crises are conceptual and normative. The first limitation is simply one of the idiom in which the rights discourse is formulated. The language of rights, which is central to liberalism, is fraught with limitations which could be detrimental to the project of transforming deeply distorted societies. Inherent in the language of rights are indeterminacy, elasticity, and the double-edged nature of the rights discourse. All these characteristics open the rights language to malleability, misuse by malignant social elements, and make them a tool in the

6 See in this respect MaKau Mutua, Kenya's Quest for Democracy. Taming Leviathan, Lynne Rienner Publishers, Boulder, 2008. 
hands of those opposed to reform. South Africa is a case in point where a rightbased revolution has been unable to fundamentally transform deeply embedded social dysfunction and the perverse legacy of Apartheid. The choice of the rights idiom as the medium of choice to unravel the ravages of Apartheid has been less than successful in spite of continued economic growth.

Another problem of the liberal tradition, which has been inherited by the human rights movement, is its unrelenting focus on individualism. This arises from liberalism's focus on formal equality and abstract autonomy. The human rights corpus views the individual as the center of the moral universe, and therefore denigrates communities, collectives, and group rights. This is one of the biggest assumptions of the human rights movement. This is a particularly serious problem in Africa where group and community rights are deeply embedded both in the cultures of the peoples, and exacerbated by the multinational nature of the post-colonial state. The concept of self-determination in Africa cannot simply be understood as an external problem: it must, of necessity, be understood as encompassing the many nations within a given post-colonial state. In reality, this means that individual rights of citizens within the state must be addressed in the context of group rights. Thus group rights or the rights of peoples become important entitlements if the state is to gain the loyalties of its diverse citizens.

I do not deny that individualism is a necessity for any constitutional democracy, but I reject the idea that we can, or should, stop there in Africa. That would be stunted understanding of rights from an African point of view. Indeed, for rights to make sense in the African context, one has to go beyond the individual and address group identities in the political and economic framework of the state. Even in South Africa, for example, one of the states with an avowedly liberal interpretation of the rights language, there was an accommodation of group rights to language, culture, and other forms of identity. One way political democracy deals with the question of multiple nations within one state is to grant autonomy regimes for groups or to devolve powers through forms of federalism. But the paradox for Africa is that autonomy regimes or federalist arrangements have not worked well wherever they have been tried. These schemes have been unable to stem the combustible problem of ethnicity and reduce the legitimacy of the state. Ethnic groups retain a consciousness that stubbornly refuses to transfer loyalty from the group to the whole nation.

Secondly, the human rights movement's primary grounding and bias towards civil and political rights - and the impotence and vagueness of economic, social, and cultural rights - is one of its major weaknesses in the African post-colonial context. Political democracy alone - without at least a strong welfare state or a social democracy - appears to be insufficient to recover the African state. The bias towards civil and political rights favors vested narrow class interests and 
kleptocracies which are entrenched in the bureaucratic, political, and business sectors of society and represent interests that are not inclined to challenge the economic powerlessness of the majority of post-colonial Africans. Yet the human rights movement assumes the naturalness of the market and the inevitability of employer/employee, capitalist/worker, and subordinated labor relations. It seeks the regulation of these relationships, but not their fundamental reformulation.

By failing to interrogate and wrestle with economic and political philosophies and systems, the human rights movement indirectly sanctions capitalism and free markets. Importantly, the human rights corpus wrongly equates the containment of state despotism with the achievement of human dignity so that it seeks the construction of a political society in which political tyranny - not economic tyranny - is circumscribed. But in so doing, it sidesteps economic powerlessness - the very condition that must be addressed if the African state is to be recovered. Clearly, political freedoms are important, but as South Africa has demonstrated, these are of limited utility in the struggle to empower populations and reduce the illegitimacy of the state. It is an illusion to think of powerlessness and human indignity in the African context in purely political terms, as the human rights movement does, and to prescribe political democracy and the human rights doctrine as a panacea.

Real human powerlessness and indignity in Africa - the very causes of the illegitimacy of the African state - arise from social and economic conditions. That is why the human rights movement's recognition of secularism, capitalism, and political democracy must be discussed openly to unveil its true identity so that we can recalculate its uses, and the limitations of those uses, to the reconstruction of the African state. To be useful to Africa's reconstruction, human rights cannot simply be advocated as an unreformed Eurocentric doctrine that must be gifted to native peoples. Nor can it be imposed on Africa like an antibiotic, or be seen as a cure for the ills of a dark continent. I am afraid that this is how many in the West imagine what for them is a human rights crusade towards Africa. So far, this law and development model has not - and will not - work. Not only is it an imposition, but it would also deal mostly with symptoms, while leaving the underlying fundamentals untouched.

To be of utility to Africa, and fundamentally transform the continent's dire fortunes, human rights must address economic powerlessness and the scandalous international order. Otherwise, it will promise too much, while delivering too little, as it did in the case of Rwanda with the establishment of the International Criminal Tribunal and a false peace within the country. It will promise too much, while delivering too little, as it did in the wave of the so-called Second Liberation. The challenge for us is to figure out how we can retool and rethink the human rights project as one of the vehicles for the reconstruction of the 
African post-colonial state. I am afraid that this is a task for which we have been found wanting.

\section{RECONCEIVING TRANSITIONAL JUSTICE}

Transitional justice concepts have to be freed from dogmatic universality to be useful to Africa. In this regard, notions of transitional justice ought to be reconstructed so that they are informed by a wider moral and social universe. The key to a successful transitional justice agenda is to imagine a more holistic approach to addressing human relationships in post-conflict, post-colonial situations. Reparative, retributive, and adversarial notions of justice are limited, and may not be wholly legitimate in the eyes of victims. Sanctions against perpetrators - whether criminal, civil, or political - are important in any transitional justice concept, but they are not enough. The problem is that such sanctions are not at the core victim-centered. Criminal sanctions, for example, are the revenge that society takes against the wrongdoer. Thus such sanctions mollify society at large, but may do nothing for the victim. Civil sanctions, too, such as compensatory damages respond to the material, and not the spiritual or metaphysical. Thus although the victim may be returned to the status quo ante, the restoration of material things may do nothing to heal the soul - the injured identity of gender, ethnicity, race, religion, political opinion, or social status.

That is why I agree with Alex Boraine's 'holistic' approach to transitional justice and the five-pillar approach that combines elements of accountability, truth recovery, reconciliation, institutional reforms, and reparations in one grand package of social reclamation. ${ }^{7}$ A wider array of tools and approaches are necessary to address powerlessness in all its dimensions - social, economic, political, gender - to create a deeper democratic polity capable of repairing most hurts. ${ }^{8}$ It is these approaches that can ultimately tackle the hydra of impunity that corrupts the body politic and makes it virtually impossible for society to cohere into a nurturing instrumentality. That is why notions like ubuntu - the African philosophy of community wholesomeness - must be conceived as a new linchpin for the recovery of post-conflict societies. ${ }^{9}$ This is not to say that traditional iterations of transitional justice contained in international humanitarian, human rights, and international criminal law are vacuous or invalid. Rather, it is to recognize their limitations in addressing deeply embedded

\footnotetext{
7 Alex Boraine and Sue Valentine (eds.), Transitional Justice and Human Security, International Center for Transitional Justice, Cape Town, 2006.

8 Kieran McEvoy and Lorna McGregor (eds.), Transitional justice from below. Grassroots activism and the struggle for change, Hart, Oxford, 2008.

9 Yvonne Mokgoro, "Ubuntu and the Law in South Africa," in 4 Buffalo Human Rights Law Review, 15, 1998.
} 
social dysfunctions that require more than criminal or civil sanction approaches.

In fact, the histories of several highly touted traditional transitional justice mechanisms point to these limitations. This is particularly true of international criminal tribunals, and much less so of truth commissions. Take the International Criminal Tribunal for Rwanda and the International Criminal Tribunal for the former Yugoslavia, for example. The ICTR followed the script of the Nuremberg tribunal. But it is clear that as constituted, the Rwanda Tribunal was intended to achieve neither the abolitionist impulses nor the just ends trumpeted by the United Nations. The tribunal is still disarticulated from political reconstruction and the normalization processes necessary to bring humanity back to Rwanda. In the event, the Rwanda tribunal largely legitimizes the Tutsi regime and allows the Tutsi a moral plane from which to exact their revenge on the Hutu. The Rwanda tribunal would have made more sense in the context of a holistic and comprehensive settlement addressing the foundational problems that unleashed the genocide in the first place. As it is, the tribunal orbits in space, suspended from political reality and removed from both the individual and national psyches of the victims as well as the victors in the Rwanda conflict. ${ }^{10}$ The same analysis is applicable to the ICTY where Serbs have seen themselves as its victims. The result is a failure of both institutions to inch society towards healing.

The Special Court for Sierra Leone has had more mixed, but arguably, promising results because it was situated in the country itself, and not outside, as are the cases with the both the Rwanda and Yugoslav tribunals. But the International Criminal Tribunal for Iraq, though situated in Iraq, has been largely a sham from both domestic and international perspectives. It lacks credibility with Sunnis who see it merely as a tool for revenge by the Shiites and the occupying American forces. Its unacceptably unfair, biased, and compromised procedures and the absence of due process protections have made it a mockery of transitional justice. It remains to be seen whether the International Criminal Court can address some of these deficits, or remain simply as the darling of lawyers who see its utility as developing international criminal and humanitarian law, or Western politicians who see it as an instrument for assuaging their consciences for societal failures about which they did nothing - or very little - to stop.

The key ultimately is to understand that none of these processes - truth commissions, tribunals, sectoral reforms, prosecutions, and others - will suffice by themselves unless they are thought about and implemented in a holistic context that addresses the multiple, and often conflicting, vistas of

10 See Phil Clark, The Gaçaca Courts. Genocide Justice and Reconciliation in Rwanda: Justice without Law yers, Cambridge University Press, Cambridge, 2010. 
powerlessness. ${ }^{11}$ Here, building a democratic culture that is not just premised on political rights, and tackling impunity, will be key to the society of the future. I am not arguing that we should turn away from traditional systems of transitional justice. Rather, I am arguing that these systems are incomplete and ineffective because they do not focus on people and victims, but are rather concerned with vindicating their own internal norms.

\section{THE LIMITATIONS OF TRANSITIONAL JUSTICE CONCEPTS}

To be meaningful for Africa, transitional justice concepts should be comprehensive and all-inclusive if they are to break with past orthodoxies. I want to suggest a multi-cultural perspective in crafting effective solutions to legacies of conflict. In this view, I am alluding to the limits of normative Eurocentrism in the doctrine of international law. ${ }^{12}$ While this critique of the exclusivity of international legal norms is not new, it has not been fully developed in human rights law and international humanitarian and criminal law. Yet these are critiques are completely essential if transitional justice systems are to have any hope of success in the tormented societies in Africa. Without a doubt, my analysis demands is a tall order. The question is whether there is both intellectual rigor on the part of academics and political will and vision on the part of states, civil societies, and policymakers to carry through. These are questions which are complicated by the histories of conflict and the memories they leave behind.

A survey of the anatomy of conflicts in the larger East African region - Kenya, Uganda, Rwanda, Sudan, and Burundi shows that democracy has not fared well. As such, many of these states are undergoing different iterations of 'transitions' from one thing or another. What is clear, however, is that these 'transitions' have not accomplished much, and there indeed have been many reversals. Take, for example, the near collapse of Kenya after the 2007 elections just five years removed from the successful 2002 elections in which there was regime change for the first time. Obviously, the 'transition' between 2002-2007 was not a successful one..$^{13}$ In Rwanda, Tutsi hegemony has once again been re-established under the guise of 'democracy' and post-conflict transitional justice 'reconstruction'. Burundi remains tense. In Sudan, an unstable peace barely holds in the south whereas in the west region of Darfur the government is

11 Pablo De Greiff and Roger Duthie (eds.), Transitional Justice and Development. Making Connections, Social Science Research Council, New York, 2009.

12 Antony A NGHIE, Imperialism, Sovereignty, and the Making of International Law, Cambridge University Press, Cambridge, 2005; James Thuo Gathir, "Imperialism, Colonialism, and International Law," 54 Buffalo Law Review 1013, 2006.

13 Makau Mutua, Kenya's Quest for Democracy..., op. cit. 


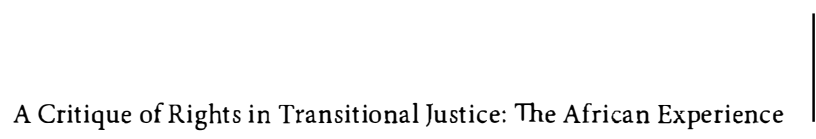

committing genocide. How can you have a 'transition' in one part of the country while committing genocide in the other? In Uganda, President Yoweri Museveni is creating the conditions for a perfect storm both in the north and everywhere else because of political despotism and a failed transition to democracy.

My panacea here is a call to go beyond tired notions of transitional justice and introduce fuller concepts of 'restorative justice' that move away from criminal law formulations of sanctions, and instead employ alternative dispute resolution paradigms such as indigenous courts, juvenile justice ideas, and other novel vehicles that imagine the possibility of restoring a lost social balance. It is this lost social balance which is the chasm that has caused the conflicts in the first place. Some may attack this approach based on the localization of the practices and norms, but I want to argue instead that dominant Eurocentric cultures suffer from an over-emphasis of retribution, although they too have elements of restorative justice. Virtually all cultures have restorative justice impulses in them. But what is needed is the multiculturalization of transitional justice to give it a truly universal imprint much in the same way that the human rights corpus has been asked to become less Eurocentric and more inclusive. ${ }^{14}$ There is some hope as evidenced by the Ron Claassen's Principles of Restorative Justice ${ }^{15}$ and by the UN Basic Principles on the use of Restorative Justice Programmes in Criminal Matters ${ }^{16}$ that transitional justice must move beyond the punitive to the more restorative, comprehensive, and holistic transitional justice model. These principles are guided by their ability to heal; put victims at the center; seek cooperation with perpetrators before confrontation; understand abominations as injuries to social relations; de-emphasize the punitive or criminality of offenses and emphasise the causes of the abominations; and achieve community buy-in in crafting solutions and measures for accountability. In other words, this transitional justice approach requires the full participation of all the assets of the community - traditional, ethical, religious, civil society, political, and moral. This is in marked contrast to traditional mechanisms such as truth commissions or tribunals that look primarily to formalized structures of criminal accountability and censure.

I believe that we have to re-imagine the transitional justice agenda along these holistic perimeters, although I want to caution that this is an arduous project. Secondly, it is important that the project not evacuate the progress made by traditional transitional justice systems. For example, it is clear that truth commissions have their naked limitations. Even the most famous ones - such as

\footnotetext{
14 Makau Mut ua, Human Rights: A Political and Cultural Critique, supra note 4.

15 "Principles of Restorative Justice", The Alternative, Newsletter of the Dispute Resolution Center of Snohomish and Island Counties, Washington, Spring 1997.

16 ECOSOC, Resolution 2002/12, 24 July 2002.
} 
South Africa's - have still left a lot to be desired. Most of them lack the political backing or framework to dig at the roots of the abominations, or really expose the rot that led to the pogroms in the first place. Most have been hampered by the cultures of impunity in which they were incubated. After all, how do the forces of reform - which are usually a minority in states emerging out of conflict - marshal enough political resources to overcome former regime elements?

In Kenya, for instance, the Report of the Task Force for the Establishment of a Truth, Justice, and Reconciliation Commission which I produced was buried by anti-reform elements in the Kibaki Government, even though it came to power on a clear mandate fundamental change. ${ }^{17}$ Six years later, the same people who shot down a truth commission are ostensibly interested in setting one up after the genocidal violence of the 2007 elections. One has to wonder whether political interests have changed so much as to permit a genuine truth commission to be established in Kenya. Have Kenyans learnt any useful lessons between 2002 and today that could be used to craft a more effective transitional justice project? Evidence suggests that the pogroms of the election aftermath indicate a deeper national psychosis that cannot be "cured" by a traditional truth commission or a retributive justice system alone. The nature of the abuses that took place, the proclivity of the political class to stoke ethnic hatreds, and the receptivity of the populace to misogyny and other identity hatreds suggests that a holistic approach to transitional justice is the only viable bridge to the future. The adoption of the new Constitution in 2010 can be seen as an opportunity towards such transformation. ${ }^{18}$

We can employ dichotomy as a device to illustrate why traditional transitional justice notions have experienced large deficits. In this device, we can imagine a process de-dichotomization that is designed to free transitional justice from the tyrannies of Eurocentric legal paganism. The point of departure here is that dualism is a proclivity of Western liberal philosophy and the public imagination. Thus good only makes sense in the face of evil, or right exists because of wrong. This white over black, superior/inferior, modern/traditional, savage/victim, progress/backward dualism has been an integral theme in European civilization. ${ }^{19}$ These dichotomies create illusions of moral certainty and policy inflexibility. Given this fixity, it is no wonder that there is reluctance within powerful countries and vested interests to entertain social, political, and legal experimentation. This includes trials of emergent ideas in the area of transitional justice. However, I want to suggest that we break these dichotomies down because

17 Republic OF KenYa, The Report of the Task Force on the Establishment of Truth, Justice, and Reconciliation Commission, 2003.

18 See M. АКЕСН, Institutional Reform in the New Constitution of Kenya, ICTJ, New York, 2010.

19 Makau Mutua, "Savages, Victims, and Saviors: the Metaphor of Human Rights," 42 Harvard International Law Journal, 201-245, 2001. 
it is self-defeating to create water-tight categories that artificially stop social phenomena from naturally bleeding into each other. Whatever we do, it is not productive to bifurcate for the sake of it, either because jurists think it is heresy not to bifurcate, or politicians are afraid that holistic approaches will reach to the bottom of the problem.

It is important to debunk one after the other of the many dichotomies of modern Western civilization. For example, the modern/traditional schism imprisons us in a false jail and makes it difficult for us to cultivate non-Western notions to enrich transitional justice ideas. Another old-line distinction is between law and politics, or the humanities. To traditional legal minds, law is supposed to be the neutral arbiter of social conflict and the dispassionate source of the allocation of power and its uses. Law is supposed to be impartial and objective whereas politics is partisan and biased. The human rights movement was very good at insisting on this dichotomy at the height of the Cold War for fear that it would be delegitimized as a tool for the capitalist, liberal, and political democratic West. ${ }^{20}$ These distinctions even found their way into the demonization of economic and social rights as not rights at all in the way that political and civil rights are conceived in liberal, market societies. This opposition was voiced at a meeting to consider the ratification of the International Covenant on Economic, Social and Cultural Rights:

'One participant felt strongly that it would be detrimental for US human rights NGOs to espouse the idea of economic, social and cultural rights. Although they refer to important issues, they concern distributive justice rather than corrective justice, like civil and political rights. But distributive justice is a matter of policy, rather than principles; and human rights NGOs must deal with principles, not policies. Otherwise, their credibility will be damaged. Supporting economic demands will only undermine the ability of NGOs to promote civil and political rights. ${ }^{21}$

Attempts to locate political and civil rights in a different normative plane than economic and social rights - while attentive to political biases - have no scholarly defense or argument simply because it is impossible to imagine a right in one category that does not implicate a right in the other. As an analytical question, the distinction is purely fictional and has no bases in a normative argument. The same is true of the distinction between law and politics or the humanities. For the purposes of social transformation, such distinctions only serve to limit the

20 Thomas Carothers, "Democracy and Human Rights: Policy Allies or Rivals?," 17 Washington Quarterly 106, 1994.

21 Mara Rodriguez Bustelo and Philip Alston, Report of a Conference Held at Arden House, 1986, quoted in "US Ratification of the Covenant on Economic, Social and Cultural Rights: the Need for an Entirely New Strategy," 84 American Journal of International Law 365-390, 1990. 
potential of the transitional justice vehicles. ${ }^{22}$ Thus international criminal law needs to imagine itself as not in isolation from either geopolitics, or the national political interests that animate and motivate political actors who will be subject to transitional justice projects. Nor would it make much sense for retributive justice processes to pay no attention to - or be separated from - the economic and social needs of women victims, for instance. What kind of a lasting or effective solution would only focus on criminal sanctions for perpetrators while leaving completely unattended the moral and material needs of vulnerable individuals and groups in society? Would that not simply leave intact the power structures of yesterday and the fault lines that caused the pogroms in the first place? If such an approach does not address powerlessness in all its multidimensions, how would it hope to deal with impunity? The integration of various normative approaches that touch on the human condition is the only viable method.

Other dualisms that vex transitional justice may include the use of criminal law without examining what civil law measures might be added. One looks at social wrongs as an affront on the individual while the other sees an offense as a wrong committed against the public. The search for a national peace that is substantive for individuals and communities cannot afford to put the two approaches at logger-heads. Instead, both should be integrated in a wholesome process. The same is obviously true of punitive, retributive processes common in adversarial systems. An imaginative approach needs to go beyond punishment and confrontation and craft hybrid systems that combine aspects of both depending on the situation.

We can also identify the tension between national and international law as another drawback. International law, that 'gentle civilizer' of nations, is not meant to displace national or municipal law. ${ }^{23}$ That is why international criminal tribunals, for instance, are less useful if they are unconnected to transitional processes taking place within states in the aftermath of conflicts. This critique is especially applicable to both ICTR and the ICTY. But this dichotomy is extended to how conflicts are treated - whether they are national or international conflicts. So-called internal conflicts are less likely to draw international collective responses unless they are perceived to be extremely serious, or to threaten the strategic interests of the big powers. This is in spite of the fact that the impact of the conflicts on individuals and groups is not diminished by the nature of it. The dichotomy evacuates people from the center and replaces them with state

\footnotetext{
22 James l. Cavallaro and Sebastian Albuja, "The Lost Agenda: Economic Crimes and Truth Commissions in Latin America and beyond", in Kieran McEvor and LORNA MCGREGOR (eds.), Tran sitional justice from below..., op. cit., pp. 121-141.

23 MARTti KosKenniemi, The Gentle Civilizer of Nation: The Rise and Fall of International Law: 1870-1960, Cambridge University Press, Cambridge, 2001.
} 
interests. This is an additional hurdle that must be addressed by transitional justice advocates.

One can identify a cluster of schisms of justice/peace, justice/reconciliation, and justice/democracy. The assumptions here indicate that the demands of justice would be incompatible with reconciliation, peace, or democracy. This onedimensional thinking - where justice is understood as an end by itself - defeats the logic of transitional justice. By the nature of the objectives of transitional justice, it is not possible to have a winner-take-all approach. Peace requires justice, but not full-throttled revenge. Reconciliation requires justice, but not in an extreme bias against either victim or perpetrator. To redeem the perpetrator without encouraging impunity requires a degree of conciliation on the part of the victim. Finally, there is a false belief that national security can be attained without human security. ${ }^{24}$ Recent conflicts within countries - and between them - have shown that neither is possible without the other. The cases of Iraq, Afghanistan, Kenya, and even the United States amply demonstrate the folly of treating one as separate from the other.

\section{AS A WAY OF CONCLUSION}

The subject of transitional justice is a difficult and complex one, particularly because it is a work in progress. Lessons from practice are still trickling in, and it will be sometime before definitive data is accumulated. But one thing is clear we know what does not work, and what might work. What this chapter attempts to do is provide an opening to reconceptualize transitional justice projects and reformulate them from their traditionally narrow normative bases. Although it seems obvious, there has not been adequate work done on the indivisibility of the approaches to transitional justice. I am pleading for a more open mind to collapsing - or at least resisting the reification - of traditional totems of analysis and action. Human condition does not respond to abstracted categories. Rather, its complexity and density require a nuanced understanding of what will motivate individuals and groups to imagine a new and different life together. How we think about the choices that have to be made to create a viable bridge to that new society will depend on our ability to avoid intellectual rigidity and policy myopia. But none of these will bear fruit unless political actors in Africa imagine a larger vision for the continent.

24 See the reflections by the editors in the introductory chapter of this volume. 